\title{
Inhalation effect of massoilactone from massoia essential oil on lipid profile, liver tissues, and body weight of Sprague Dawley rat
}

\author{
Irmanida Batubara ${ }^{1,2^{*}}$, Yanico Hadi Prayogo ${ }^{1}$, Irma Herawati Suparto ${ }^{1,3}$, Berry Juliandi ${ }^{4}$, Susumu Uchiyama ${ }^{5}$ \\ ${ }^{1}$ Department of Chemistry, Faculty of Mathematics and Natural Sciences, Bogor Agricultural University, Bogor, Indonesia. \\ ${ }^{2}$ Tropical Biopharmaca Research Center, Bogor Agricultural University, Bogor, Indonesia. \\ ${ }^{3}$ Primate Research Center, Bogor Agricultural University, Bogor, Indonesia. \\ ${ }^{4}$ Department of Biology, Faculty of Mathematics and Natural Sciences, Bogor Agricultural University, Bogor, Indonesia. \\ ${ }^{5}$ Department of Biotechnology, Graduate School of Engineering, Osaka University, Osaka, Japan.
}

\section{ARTICLE INFO \\ Received on: 13/05/2019 \\ Accepted on: 20/06/2019 \\ Available online: 03/08/2019}

\section{Key words:}

Massoilactone, massoia oil, body weight, lipid profile, liver tissues.

\begin{abstract}
Massoia (Cryptocarya massoia) is an Indonesian endemic plant containing essential oils with massoia lactone as a dominant compound component. This study aims to clarify the inhalation effect of massoia lactone on body weight and lipid profile on Sprague Dawley rats. Chemical components of two fractionated portions among four fractions from massoia oil were identified to be composed of $97 \%$ and $1.4 \%$ massoia lactone, thus named as massoia lactone rich and poor fractions, respectively. The two fractions and massoia oil were further used for in vivo tests on four treatment groups (one group was negative control). The results showed that the experimental animals that inhaled massoia lactone rich fraction had the lowest body weight analysis of variance (ANOVA $p<0.05$ ), while the animals that inhaled massoia oil and poor massoia lactone fraction had the lowest average cholesterol and triglyceride concentrations (ANOVA $p<0.05$ ). These data indicate that the inhalation of fractionated massoia oil has the potential to decrease body weight, restrain inclining of triglycerides and cholesterol concentration in the blood. Also, the number of liver cells with a larger size than normal liver cells in rats with massoia lactone rich and poor fraction treatment was less than the negative control and treated with massoia oil.
\end{abstract}

\section{INTRODUCTION}

Massoia (Cryptocarya massoia) is one of the endemic plants of eastern Indonesia, namely, in Maluku and Papua. Massoia plants belong to the family Lauraceae. Massoia plant skin has long been used as a traditional medicinal ingredient (Cavill et al., 1968). The primary compound components in leaf, stem, and massoia oils are massoilactone, benzyl benzoate, and $\delta$-decalactone (Pons et al., 2017). Massoilactone contained in massoia oil brings very strong coconut-peach-like aroma (Arnouda et al., 2005). It is widely used as natural coconut flavor. The biological activity of the massoia oil and the massoilactone has been studied were anti-inflammatory

"Corresponding Author

Irmanida Batubara, Department of Chemistry, Faculty of Mathematics and Natural Sciences, Bogor Agricultural University, Bogor, Indonesia. E-mail:ime@apps.ipb.ac.id
(Rolli et al., 2017), analgesics (Widowati and Pudjiastuti, 1999), and antimicrobials activities in Candida albicans (Hassan et al., 2018).

Essential oils have the potential of affecting the neural activity associated with metabolism in the body, while the influence depends on the source of the oils. For example, inhalation of essential oils of Kaempferia galanga in rats as well as its compound components can reduced body weight of rats, the concentration of cholesterol and triglycerides (Batubara et al., 2014), whereas inhalation of Zingiber zerumbet oil and zerumbone compounds increased food consumption as well as increased body weight (Batubara et al., 2013). Increased and decreased body weight is certainly associated with diet in foods and beverages consumed every day and its activities. The inhalation effect of essential oils or volatile compounds contained therein is related to olfactory stimulation. This olfactory stimulation will decrease or increase the activity of sympathetic and parasympathetic nerves. For example, olfactory stimulation of grapefruit oil and lavender oil affects the autonomic nerves, lipid metabolism (lipolysis), 
increasing (grapefruit oil) and decreasing (lavender oil) appetite which is then associated with the body weight changes (Shen et al., 2005a; 2005b). The decrease of sympathetic nerve activities on brown adipose tissue is shown in rats treated with $Z$. zerumbet essential oil and zerumbone fraction, it will decreased adipose tissue temperature which increase body weight (Batubara et al., 2013).

Massoia oils have been studied for medicinal plant but not yet for aromatherapy. This oil can stimulate the olfactory through inhalation which affect sympathetic and parasympathetic nerves associated with body weight. This study was conducted to evaluate the effects of inhalation of massoilactone extracted from massoia oil on body weight, liver tissue, triglyceride levels, and total cholesterol in adult male Sprague Dawley rats.

\section{MATERIALS AND METHODS}

\section{Extraction of massoilactone}

Massoia oil used is essential oil produced by water distillation of the bark part of the massoia plant (C. massoia) which collected from Papua Island, Indonesia on September 2016. Fractionation of Massoia oil was performed using a column with silica gel $60(2 \times 41 \mathrm{~cm})$. A total of 3,7469 $\mathrm{g}$ of massoia oil were fed into the column and eluted using a stepwise elution method ( $n$-hexane, chloroform, and methanol) to separate the component of Massoia oil. Eluent flow rate was set at a speed of $0.03 \mathrm{ml}$ second $^{-1}$. Eluate was accommodated with a volume of $5 \mathrm{ml}$ and each fraction is monitored with Thin Layer Chromatography (TLC) using the best eluent. Eluate with the same TLC stain pattern combined into one fraction. The fraction obtained was then concentrated by a rotary evaporator. The Massoia oil and the fractions were then analyzed by GC-MS to identify the compound on its.

\section{GC-MS conditions}

Identification of compound in massoia oil and its fractions were carried out by using gas chromatography mass spectrometry (GC-MS) instrument (Agilent, 15977A series). Sample volume of $1 \mu \mathrm{l}$ was injected (sample dissolved in $\mathrm{CHCl}_{3}$ ) into the HP-5 with dimensions of $30 \mathrm{~m} \times 0.32 \mathrm{~mm}$ and $0.25 \mu \mathrm{m}$ film thickness. The injector temperature was set at $300^{\circ} \mathrm{C}$. The regulated oven temperature increases starting at $80^{\circ} \mathrm{C}-290^{\circ} \mathrm{C}$ at a rate of $15^{\circ} \mathrm{C}$ minute $^{-1}$. The carrier gas used was $\mathrm{He}$ with a flow rate of $1 \mathrm{ml}$ minute $^{-1}$ and a split ratio of 50:1. Electron impact was employed for the ionization in the spectrophotometer at the reading rate of 1 scan second ${ }^{-1}$ with the detection area of 45-450 Da. Furthermore, compound was identified based on mass spectrum using the NIST library. For the Kovat Index, the C7-C40 n-alkanes was identified with the same column for massoia oil identification.

\section{In vivo analysis}

Sprague Dawley's 28 male adult males with a weight of $300-400 \mathrm{~g}$ at 12 weeks were used for in vivo tests. Every three rats were placed in a $40 \times 30 \times 20 \mathrm{~cm}^{3}$ cage. Animals went through 1 week of adaptation period for environmental, physiological, and nutrition adaptation. The rats were fed a high-fat diet (HFD) and ad libitum drinking water added with propylthiouracil (PTU) $0.01 \%(\mathrm{w} / \mathrm{v})$ concentration. After the adaptation period, rat blood was taken through the vein of the tail and then used in the analysis of total cholesterol and triglycerides (baseline). All the animals were randomly grouped into four groups (seven individuals in each group) based on their body weight. Group I was a negative control (without inhalation treatment). Groups II, III, and IV were inhaled with massoia oil, massoia lactone fraction (MF), and less massoia lactone fraction (LF) which diluted $1,000 \times$ in water, respectively. Description of inhalation administration based on Damayanti et al. (2015). After 5 weeks of the treatment, animals were fasted overnight and sedated by using a combination of ketamine and xylazine, with a dosage of 80 and $10 \mathrm{mg} / \mathrm{kg}$ body weight, respectively. Animals were then euthanized by exsanguination. Liver and adipose tissue from the scrotal and mesenteric areas were weighed, as well as rat blood samples were analyzed using specific kits manufactured from ST Reagensia (Jakarta, Indonesia) to determine the lipid profile (total cholesterol and triglyceride). All the procedures with animals were approved by the animal ethics committee of Bogor Agricultural University No. 61-2017IPB on 9 June 2017.

\section{Histopathological examination}

The collected rat liver was examined for the condition of the cells. Preparatory samples were taken in two organs in each group. The right liver lobes were fixed in $4 \%$ paraformaldehyde after dehydration tissue samples were embedded in paraffin. Blocked tissues were cut into 4-5 $\mu \mathrm{m}$ thickness with a microtome. The serial sections stained with hematoxylin and eosin (HE) for histopathological interpretation and examined under a light microscope (Nikon Eclipsed $80 \mathrm{E}$ ) at $40 \times$ magnification by a certified pathologist. Interpretation of liver cells changes was analyzed semiquantitatively between groups and performed accordingly to Gibson-Corley et al. (2013) by certified pathologies.

\section{Statistical analysis}

The data for feed consumption, body, adipose tissue, and liver weight were analyzed using a completely randomized block design and with an analysis of variance (ANOVA) at a confidence level of 95\% using SPSS 22. The Duncan's multiple test range was also used.

\section{RESULT AND DISCUSSION}

Fractionation of massoia oil produces four fractions with two fractions classified as fractions with the dominant content of masoilactone and less-massoia. Results on the identification of compound from massoia oil, massoilactone rich fraction (MF),

Table 1. Compound content in massoia oil, massoia lactone fraction, and less massoia lactone fraction and its Kovat retention index.

\begin{tabular}{lcccc}
\hline \multirow{2}{*}{ Compounds } & RI & \multicolumn{3}{c}{ Abundance (\%) } \\
\cline { 3 - 5 } & & Massoia oil & MF & LF \\
\hline Borneol & 1,210 & 1.47 & 0.25 & - \\
C10 massoia lactone & 1,520 & 48.16 & 41.27 & - \\
$\delta$-decalactone & 1,524 & - & - & 34.05 \\
$\beta$-Bisabolene & 1,555 & 1.65 & 0.29 & - \\
C12 massoia lactone & 1,739 & 45.15 & 55.64 & 1.39 \\
$\delta$-dodecalactone & 1,749 & - & - & 4.17 \\
C14 massoia lactone & 2,068 & 0.72 & - & - \\
\hline
\end{tabular}

Kovats retention index relative to $\mathrm{C} 7-\mathrm{C} 40$ n-alkanes on the HP-5MS capillary column. 


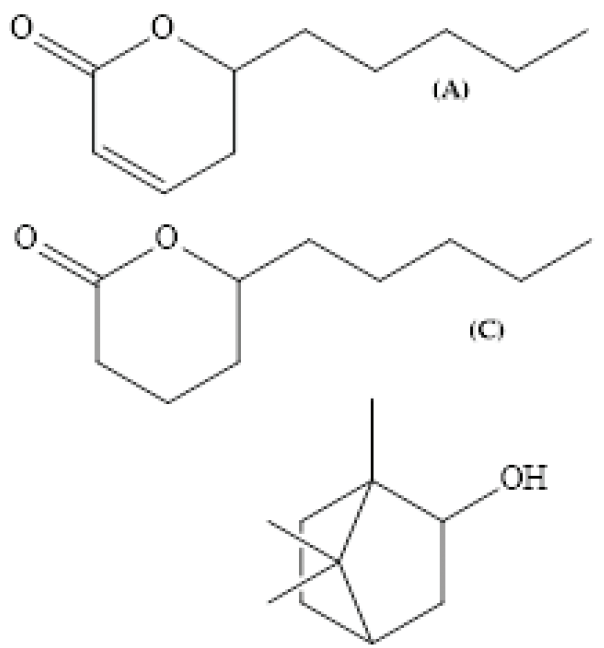

(E)
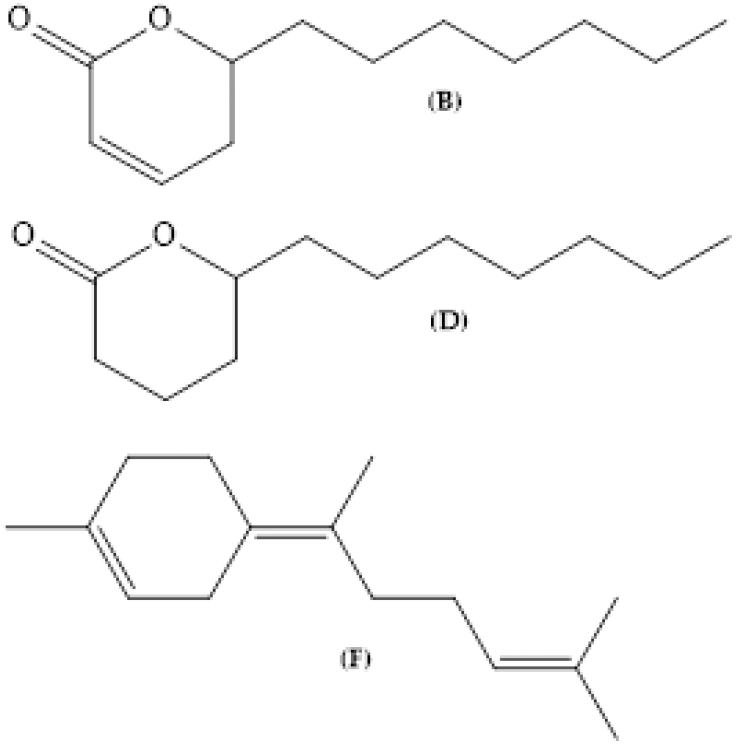

Figure 1. Structure of compounds in massoia oil, MF, and LF. (A) C10 massoilactone; (B) C12 massoilactone; (C) $\delta$-decalactone; (D) $\delta$-dodecalactone; (E) borneol; and (F) $\beta$-bisabolene.

Table 2. Average body weight and feed consumption in all groups.

\begin{tabular}{lcccc}
\hline \multirow{2}{*}{ Groups } & \multicolumn{2}{c}{ Body weight (gram) } & \multicolumn{2}{c}{ Feed consumption (g/animal) } \\
\cline { 2 - 5 } & $\begin{array}{c}\text { Before } \\
\text { treatment }\end{array}$ & $\begin{array}{c}\text { After } \\
\text { treatment }\end{array}$ & $\begin{array}{c}\text { Before } \\
\text { treatment }\end{array}$ & $\begin{array}{c}\text { After } \\
\text { treatment }\end{array}$ \\
\hline Negative control & $356 \pm 25^{\mathrm{a}}$ & $399 \pm 7^{\mathrm{a}}$ & $13 \pm 2^{\mathrm{a}}$ & $12 \pm 1^{\mathrm{a}}$ \\
HFD + massoia oil & $356 \pm 26^{\mathrm{a}}$ & $399 \pm 6^{\mathrm{a}}$ & $13 \pm 2^{\mathrm{a}}$ & $12 \pm 2^{\mathrm{a}}$ \\
HFD + MF & $356 \pm 18^{\mathrm{a}}$ & $390 \pm 7^{\mathrm{b}}$ & $13 \pm 2^{\mathrm{a}}$ & $11 \pm 2^{\mathrm{a}}$ \\
HFD + LF & $356 \pm 26^{\mathrm{a}}$ & $399 \pm 7^{\mathrm{a}}$ & $12 \pm 2^{\mathrm{a}}$ & $12 \pm 1^{\mathrm{a}}$ \\
\hline
\end{tabular}

Number that is followed by the same superscripts was not significantly different $(p>0.05)$ (Duncan's multiple range test).

and massoilactone poor fraction (LF) are shown in Table 1 and the structure compound are shown in Figure 1, consistent with the previous results. The classs of lactone compounds (massoilactone and $\delta$-lactone) and some terpene group compounds were contained as dominant compounds (Rali et al., 2007; Rolli et al., 2017). Massoia oil has a similar odor to MF, but different from LF. Identification of (R)-C10-massoilactone has been reported as a characteristic compound, reminiscent of coconut and dried figs, in must and in red wines marked by dried fruit flavors (Pons et al., 2017). Hereinafter, the effects of massoia oil and massoilactone inhalation on rats were investigated.

The olfactory stimulation of aroma of essential oils and their constituent compounds were reported to affect the autonomic nerves, including both (sympathetic and parasympathetic nerves). Olfactory stimulation of the aroma increases the activity of the sympathetic nerves, vice versa the parasympathetic nerve activity decreases. Therefore, it will decrease appetite which will lead to weight reduction, also increased the lipolysis reaction and larger heat production (higher energy consumption). Likely, the olfactory stimulation resulted in the weight reduction was identified previously in rats inhaled by grapefruit oil (Shen et al., 2005a). However, the opposite effect was also confirmed in rats treated with lavender oil (Shen et al., 2005b). Inhalation of citronella oil and its fraction also shows an effect on increased sympathetic nerve activity which has an effect on decreased appetite and increased thermogenesis of brown adipose tissue (Batubara et al., 2015).

The average body weight of rats treated with MF at the end of the treatment period was significantly different from the rats treated with massoia oil, LF, and negative controls $(p<0.05)$ (Table 2$)$. The average feed consumption was not significantly different in all the groups $(p>0.05)$ (Table 1$)$. However, observing data on average feed consumption in each group per week shows feed consumption in each group also decreased in the last 3 weeks of the treatment period. Rats treated with MF had the lowest consumption in the last 2 weeks (Fig. 2).

The decrease in feed consumption in the last 3 weeks of the treatment period correlated with a decrease in body weight (Fig. 3). Rats treated with MF had the lowest feed consumption in the last 2 weeks of the treatment period and also had the lowest average body weight. Rats treated with MF also had lower weights of adipose tissue deposits than the other two treatments (massoia oil and LF-treated groups). However, there was no significant difference in the weight of the adipose tissue among all groups. This shows that the higher concentration of massoilactone and the lowest concentration of terpene (borneol and $\beta$-bisabolene) effectively affects the decrease in rat body weight compared to massoia oil. In addition, massoia lactone compounds also had different effects compared to other lactone compounds found in LF ( $\delta$-decalactone and $\delta$-dodecalactone). Animals treated with massoia oil and LF tend to experience changes in the same body weight and it can be seen in the adjacent graph (Fig. 3).

The effect of differences in the concentration of compounds on the effects of inhalation has been reported in previous studies. Eugenol fraction had an inhalation effect as contrary to the clove essential oil which also contained eugenol compounds as the dominant component (Hasim et al., 2016). Also, allegations about the effects of $\beta$-bisabolene compounds in red galangal essential oil were thought to cause an increase in body weight of test animals (Damayanti et al., 2015). In addition, borneol compounds are also thought to have the same effect as $\beta$-bisabolene. 


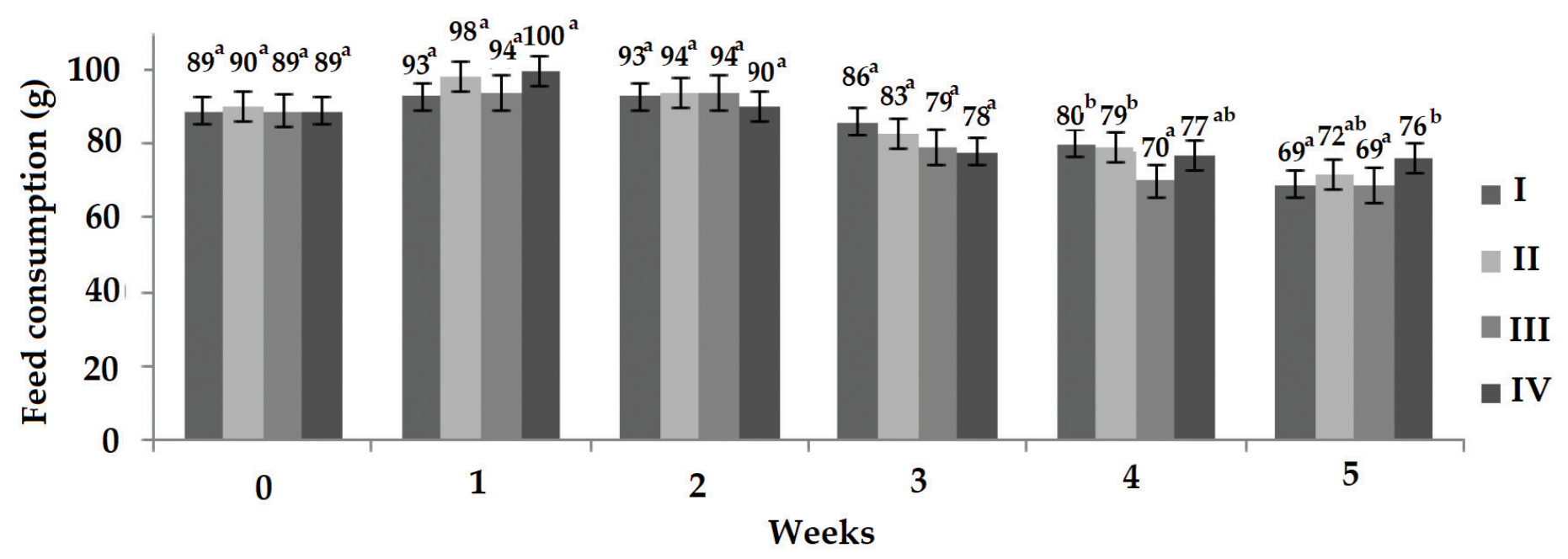

Figure 2. Average feed consumption per week during the period of adaptation and treatment.

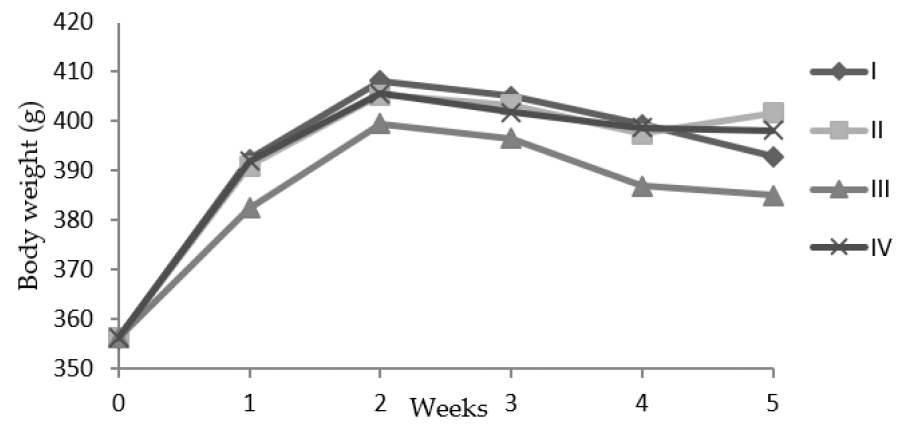

Figure 3. Changes in average body weight of rats during the treatment period of the in vivo test in all groups. (•) significantly different (ANOVA $p<0.05$ ).

At the end of the treatment period, all the groups had higher cholesterol levels than normal limits $\left(<200 \mathrm{mg} \mathrm{dl}^{-1}\right)$, also than the beginning of treatment. Rats treated with massoia oil had the lowest average cholesterol concentration (Table 3). Rats treated with MF and LF were not significantly different. This indicated that massoia lactone did not have an effect on decreasing cholesterol concentration. Conversely, the difference in concentration of terpene group compounds ( $\beta$-bisabolene and borneol) found in massoia oil and MF gave a significant difference in the value of cholesterol concentration ( $66.39 \mathrm{mg} \mathrm{dl}^{-1}$ ), while the control group was $81.45 \mathrm{mg}$ $\mathrm{dl}^{-1}$. Based on these data, massoia oil, especially terpenes contained in it, was thought to have the potential to reduce cholesterol because it can withstand an increase in cholesterol concentration due to consumption of high cholesterol diets. $\beta$-bisabolene in red galangal oil was thought to be able to withstand an increase in total cholesterol concentration in test animals (Damayanti et al., 2015).

Triglyceride concentration after treatment had the highest percentage increase in the negative control group (45\%) compared to the other three groups. Massoia oil inhalation group (massoia lactone 94.03\%), MF (massoia lactone 96.91\%), and LF (massoia lactone 1.39\%) had the percent increase of triglyceride concentration of $32 \%, 25 \%$, and $16 \%$, respectively. Based on the concentration of compounds in massoia oil and massoia lactone fraction (Table 1), the lower concentration of massoia lactone and the higher concentration of terpene compounds probably could
Table 3. Adipose tissue weight, cholesterol and triglyceride concentrations in blood in all groups.

\begin{tabular}{|c|c|c|c|c|c|}
\hline \multirow[b]{2}{*}{ Group } & \multirow{2}{*}{$\begin{array}{l}\text { Adipose tissue } \\
\text { deposite } \\
\text { (gram) }\end{array}$} & \multicolumn{2}{|c|}{ Cholesterol (mg dl${ }^{-1}$ ) } & \multicolumn{2}{|c|}{ Triglyceride ( $\mathrm{mg} \mathrm{dl}^{-1}$ ) } \\
\hline & & $\begin{array}{c}\text { Before } \\
\text { treatment }\end{array}$ & $\begin{array}{c}\text { After } \\
\text { treatment }\end{array}$ & $\begin{array}{c}\text { Before } \\
\text { treatment }\end{array}$ & $\begin{array}{c}\text { After } \\
\text { treatment }\end{array}$ \\
\hline HFD & $12.57 \pm 2.24^{\mathrm{a}}$ & $\begin{array}{c}102.08 \pm \\
18.54^{\mathrm{a}}\end{array}$ & $\begin{array}{c}310.34 \pm \\
81.06^{\mathrm{b}}\end{array}$ & $\begin{array}{c}46.90 \pm \\
15.71^{\mathrm{a}}\end{array}$ & $\begin{array}{c}68.03 \pm \\
4.72^{\mathrm{ab}}\end{array}$ \\
\hline $\begin{array}{l}\text { HFD }+ \\
\text { massoia oil }\end{array}$ & $14.19 \pm 3.55^{\mathrm{a}}$ & $\begin{array}{c}102.69 \pm \\
23.72^{\mathrm{a}}\end{array}$ & $\begin{array}{c}228.89 \pm \\
51.61^{\mathrm{a}}\end{array}$ & $\begin{array}{c}57.17 \pm \\
31.75^{\mathrm{a}}\end{array}$ & $\begin{array}{l}75.34 \pm \\
21.89^{\mathrm{b}}\end{array}$ \\
\hline $\mathrm{HFD}+\mathrm{MF}$ & $13.78 \pm 2.54^{\mathrm{a}}$ & $\begin{array}{c}103.67 \pm \\
24.92^{\mathrm{a}}\end{array}$ & $\begin{array}{c}295.28 \pm \\
44.33^{\mathrm{ab}}\end{array}$ & $\begin{array}{c}50.30 \pm \\
20.55^{\mathrm{a}}\end{array}$ & $\begin{array}{l}62.92 \pm \\
9.86^{\text {ab }}\end{array}$ \\
\hline $\mathrm{HFD}+\mathrm{LF}$ & $14.24 \pm 3.83^{\mathrm{a}}$ & $\begin{array}{c}101.77 \pm \\
14.11^{\mathrm{a}}\end{array}$ & $\begin{array}{c}285.36 \pm \\
81.82^{\mathrm{ab}}\end{array}$ & $\begin{array}{c}46.97 \pm \\
27.23^{\mathrm{a}}\end{array}$ & $\begin{array}{c}54.57 \pm \\
10.91^{\mathrm{a}}\end{array}$ \\
\hline
\end{tabular}

Number that is followed by the same superscripts was not significantly different $(p>0.05)$ (Duncan's multiple range test).

Table 4. Liver weight in all groups.

\begin{tabular}{lc}
\hline Treatment groups & Liver weight $(\mathrm{g})$ \\
\hline HFD & $9.27 \pm 0.92^{\mathrm{ab}}$ \\
HFD + massoia oil & $10.09 \pm 1.26^{\mathrm{b}}$ \\
HFD + MF & $8.77 \pm 0.99^{\mathrm{a}}$ \\
HFD + LF & $9.50 \pm 0.97^{\mathrm{ab}}$ \\
\hline
\end{tabular}

Number that is followed by the same superscripts was not significantly different $(\boldsymbol{p}>0.05)$ (Duncan's multiple range test).

affect an increase triglycerides concentration. On the other hand, LF which contained $\delta$-decalactone $(34.05 \%)$ and $\delta$-dodecalactone $(4.17 \%)$ had the lowest percentage increase. From these data, $\delta$-decalactone and $\delta$-dodecalactone compounds were thought to have the potential to reduce blood triglyceride concentrations.

Table 4 shows average liver weight of the group treated with MF was significantly different from massoia oil and not significantly different from negative control and LF (ANOVA $p>0.05)$. The liver is a very important organ in regulating the metabolism of proteins, carbohydrates, and fats (Cox and Nelson, 2008). Inhalation of essential oils has previously been known to affect appetite (Batubara et al., 2014; Damayanti et al., 2015; Hasim et al., 2016). This appetite will also be related to the number of calories consumed per day. The amount of calories consumed 


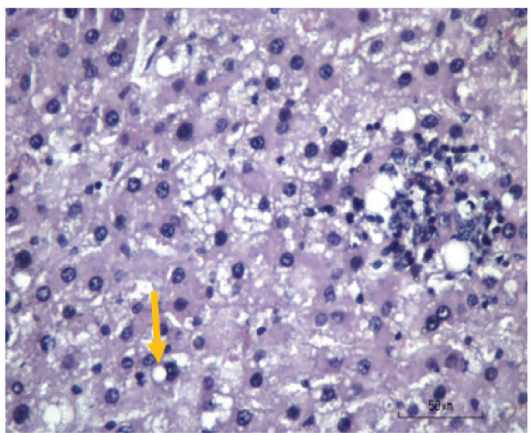

(a)

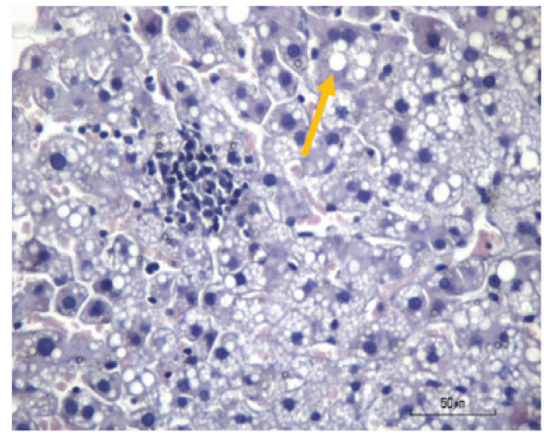

(c)

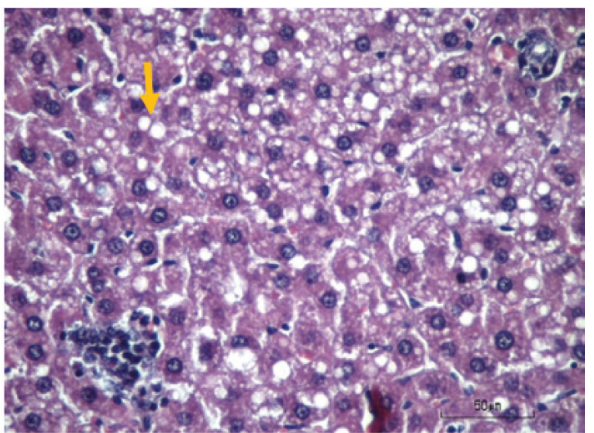

(b)

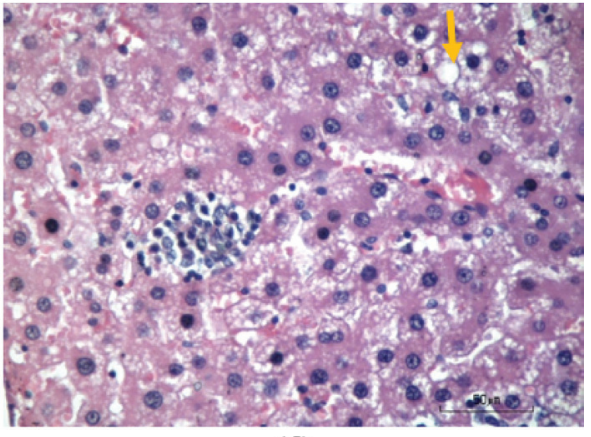

(d)

Figure 4. Photomicrograph of liver section. (a) Negative control group (without inhalation treatment), (b) Massoia oil-treated group, (c) MF-treated group, and (d) LF-treated group. The orange arrow indicates the enlargement of the vacuole.

will have an effect on the liver. The animals in this study were fed higher content of fat which in the form of triglycerides can accumulate in the liver. This was done to mimick the diet of western diet which are higher in fat. The presence of fat in the liver will be associated with fat liver disease. The number of calories consumed had the greatest influence on the fat liver disease compared to the composition of the diet consumed (Green et al., 2014). In this study, inhalation of the rich massoilactone fraction can reduce appetite of the animals and thus can be assumed that massoilactone can help to reduce calorie consumption associated with the development of fat liver disease.

Histological analysis in rat liver in each group showed similar results for certain groups (Fig. 4). Observation of the crosssection of the liver tissue treated with massoia lactone rich and poor massoia lactone fraction showed similar results. There was little infiltration of lymphocyte cells and about $70 \%$ of hepatocyte cells were larger in size than normal hepatocyte cells, whereas rats treated with massoia oil and inhaled (negative control) experienced hepatocyte cell enlargement as well with an amount of about $90 \%$ of the total cells and also infiltration of a few lymphocyte cells.

Feeding high-fat diet had the effect of enlarging the liver. This fat effect is indicated in the yellowish color of the liver. The yellowish color may be due to the presence of fat deposition in hepatic cells which is characterized by sinusoidal dilatation (Hassan et al., 2018), so the cell size will be larger. Infiltration of lymphocyte cells indicates an inflammation. These lymphocyte cells will control the inflammation due to the activity of these adipocyte cells. Adipocyte cells in liver fat were cells that actively secrete multiple immune modulator factors in the form of pro-inflammatory cytokines, interleukin-6, and tumor necrotic factor- $\alpha$ with reactive oxygen species, all of these factors contribute to chronic inflammatory conditions and the hepatocytes injury (Hassan et al., 2018).

Enlargement of hepatocyte cells that occur in the liver in all the groups indicated the presence of fat deposits in liver cells. The number of enlarged liver cells in the group with more massoia oil treatment than in rat treated with MF and LF. Based on this, the inhalation treatment of LF and MF was likely to prevent fat deposits in liver cells due to consumption of HFD. The preventive effect may also be related to the fat content in the two fractions.

\section{CONCLUSION}

The separation of massoia lactone from massoia essential oil produced fraction with massoia lactone as a major and minor content. The results of the in vivo test showed that the massoia lactone was able to reduce the body weight of rats by reducing appetite. In addition, the inhalation of massoia oil and less massoia lactone fraction each had the potential to withstand an increase in cholesterol and triglyceride concentrations in the blood. The inhalation of massoia lactone fraction and less massoia lactone fraction effects were also thought to prevent fat deposition in liver cells.

\section{ACKNOWLEDGMENTS}

The author would like to thank Awal Ramadhan Ritonga who has provided massoia oil that used as material in this research and Silvia Arin Prabandari as a certified pathologist who examined the histopathology of liver samples. Also, he would like 
to thank Dewan Atsiri Indonesia to give the second winner prize for this research results and to Kementerian Riset dan Teknologi, Republik Indonesia for the world-class professor program 2018 to finalizing the manuscript.

\section{AUTHORS' CONTRIBUTIONS}

Irmanida Batubara, Yanico Hadi Prayogo, and Irma Herawati Suparto designed the experiments and contributed with materials and analysis tool. Susumu Uchiyama and Berry Juliandi contributed with analysis and reviewed the manuscript. Yanico Hadi Prayogo wrote the paper.

\section{FUNDING}

This research received no external funding.

\section{CONFLICTS OF INTEREST}

The authors declare no conflict of interest

\section{REFERENCES}

Arnouda JF, Delbecque C, Perichet C, Bouillet S. Production of natural flavor and fragrance ingredients in 2003: massoia, orris, and vetiver oil. In Natural Flavors and Fragrance. ACS Symposium Series, Unied State, 2005, vol. 908, pp 21-40.

Batubara I, Assat LD, Irawadi TT, Mitsunaga T, Yamauchi. Effect of sniffing of kencur (Kaemferia galangal) essential oils in rats. Acta Hortic, 2014; 1023:123-7.

Batubara I, Suparto IH, Sadiah S, Matsuoka R, Mitsunaga T. Effect of Zingiber zerumbet essential oil on body weight of Sprague Dawley rat. Pak J Biol Sci, 2013; 16:1028-33.

Batubara I, Suparto IH, Sadiah S, Matsuoka R, Mitsunaga T. Effect of inhaled citronella oil and related compounds on rat body weight and brown adipose tissue sympathetic nerve. Nutrients, 2015; 7:1859-70.

Cavill GWK, Clark DV, Whitfield FB. Massoilactone from two species of formicine ants and some observations on constituents of the bark oil of Cryptocarya massoia. Aust J Chem, 1968; 21:2819-23.

Cox MM, Nelson DL. Lehninger principles of biochemistry. 5th edition, W.H. Freeman Company, New York, 2008

Damayanti R, Batubara I, Suparto IH. Essential oil of red galangal (Alpinia galanga (L.) Willd) rhizome as slimming aromatherapy. Int J Pharm Biol Sci, 2015; 6:283-9.

Gibson-Corley KN, Olivier AK, Meyerhoiz DK. Principles for valid histopathologic scoring in research. Vet Pathol, 2013; 50(6):1007-15.

Green CJ, Hodson L. The influence of dietary fat on liver fat accumulation. Nutrients, 2014; 6(11):5018-33.
Hasim F, Batubara I, Suparto IH. The potency of clove (Syzygium aromaticum) essential oil as slimming aromatherapy by in vivo assay. Int J Pharm Biol Sci, 2016; 7:110-6.

Hassan F, Soliman GM, Okasha EF, Shalaby AM. Histological, immunohistochemical, and biochemical study of experimentally induced fatty liver in adult male albino rat and the possible protective role of pomegranate. J Microsc Ultrastruct, 2018; 6:44-55.

Pons A, Allamy L, Lavigne V, Dubourdieu D, Darriet P. Study of the contribution of massoia lactone to the aroma of Merlot and Cabernet Sauvignon musts and wines. Food Chem, 2017; 232:229-36.

Rali T, Wossa SW, Leach DN. Comparative chemical analysis of the essential oil constituents in the bark, heartwood and fruits of Cryptocarya massoy (Oken) Kosterm. (Lauraceae) from Papua New Guinea. Molecules, 2007; 12:149-54.

Rolli E, Marieschi M, Maietti S, Guerrini A, Grandini A, Sacchetti G, Bruni R. Phytotoxic effects and phytochemical fingerprinting of hydrodistilled oil, enriched fractions, and isolated compounds obtained from Cryptocarya massoy (Oken) Kosterm. Bark. Chem Biodivers, 2017; 13:66-76

Shen J, Niijima A, Tanida M, Horii Y, Maeda K, Nagai K. Olfactory stimulation with scent of grapefruit oil affects autonomic nerves, lipolysis and appetite in rats. Neurosci Lett, 2005a; 380:289-94.

Shen J, Niijima A, Tanida M, Horii Y, Maeda K, Nagai K. 2005b. Olfactory stimulation with scent of lavender oil affects autonomic nerves, lipolysis and appetite in rats. Neurosci Lett, 2005b; 380:188-93.

Widowati L, Pudjiastuti. Khasiat analgetika kulit batang massoia (Massoia aromaticum becc.) pada mencit putih. Warta Tumbuhan Obat Indonesia. 1999; 5:11-12.

How to cite this article:

Batubara I, Prayogo YH, Suparto IH, Juliandi B, Uchiyama

$\mathrm{S}$. Inhalation effect of massoilactone from massoia essential oil on lipid profile, liver tissues, and body weight of Sprague Dawley rat. J Appl Pharm Sci, 2019; 9(08):111-116. 